\title{
Microbiological evaluation of ready-to-eat sandwiches served near hospitals and schools
}

\author{
Sadık BÜYÜKYÖRÜK, Devrim BEYAZ, Ergun Ömer GÖKSOY, Filiz KÖK, Pelin KOÇAK
}

Adnan Menderes University, Faculty of Veterinary Medicine, Department of Food Hygiene and Technology, Işıklı/Aydın/Turkey.

\begin{abstract}
Summary: The aim of this work was to evaluate the microbiological quality of ready-to-eat sandwiches made with cheese $(\mathrm{CS}, \mathrm{n}=80$ ), with fermented Turkish sausage (soudjouk) (SS, $\mathrm{n}=80)$, and with both cheese and soudjouk with salad $\left(\mathrm{Mix}^{+}, \mathrm{n}=60\right)$ and without salad (Mix- $\mathrm{n}=50$ ) from five different street vendors located near school and hospitals. Samples were examined for total aerobic mesophilic counts (AMC), yeast and moulds (YM), coliforms, Escherichia coli (E. coli), presumptive Bacillus cereus (B. cereus), coagulase positive staphylococci, Salmonella spp., and Listeria spp., especially Listeria monocytogenes (L. monocytogenes). The results of the microbiological examinations showed that $45(56.25 \%)$ and $2(2.5 \%)$ of the SS samples; $55(68.75 \%)$ and $6(7.5 \%)$ of the CS samples; $55(91.6 \%)$ and $14(23.3 \%)$ of the Mix $^{+}$samples, and $36(72 \%)$ and $4(8 \%)$ of the Mix ${ }^{-}$samples were unsuitable for consumption due to high levels of Staphylococcus aureus (S. aureus) and presumptive B. cereus, respectively. The results also showed that out of a total of 270 samples, $8(2.96 \%)$ were found to be contaminated with Listeria species; L. monocytogenes $(0.37 \%)$, Listeria ivanovii (1.85\%), Listeria grayi $(0.37 \%)$, Listeria seeligeri $(0.37 \%)$. E. coli contamination was found in the CS and Mix groups at incidences of $7.5 \%$ and $4.0 \%$, respectively. Salmonella spp. were not detected in any of the sandwich samples investigated. The high numbers of coliforms and AMC (up to $\geq 10^{6} \mathrm{cfu} \mathrm{g}^{-1}$ ) obtained from the examinations also indicated that hygienic conditions of the processed sandwiches were very poor. The results show that the sandwiches examined in this study were of great public health concern.
\end{abstract}

Key words: Microbiological quality, public health, ready to eat food, sandwich.

\section{Hastane ve okul çevresinde sunulan tüketime hazır sandviçlerin mikrobiyolojik değerlendirmesi}

Özet: Bu çalışmanın amacı, hastane ve okullar bölgesi etrafında bulunan beş farklı kafeteryadan temin edilen tüketime hazır peynirli sandviç (PS, $n=80$ ), sucuklu sandviç ( $S S, n=80$ ), peynirli ve sucuklu karışık (yeşillikli, $\mathrm{Kar}^{+} \mathrm{n}=60$ ), ve peynirli ve sucuklu karışık (yeşilliksiz, Kar $\mathrm{n}=50$ ) sandviçlerin mikrobiyolojik kalitelerini değerlendirmektir. Örnekler, aerobik mezofilik canlı (AMC), küf ve maya (KM), koliformlar, Escherichia coli (E. coli), olası Bacillus cereus (B. cereus), koagülaz pozitif stafilokoklar, Salmonella spp., ve Listeria spp. özellikle Listeria monocytogenes (L. monocytogenes) bakımından incelendi. Mikrobiyolojik incelemelerin sonuçları SS örneklerinin $45(\% 56.25)$ ve $2(\% 2.5)$ 'sinin, PS örneklerinin 55 (\%68.75) ve $6(\% 7.5)$ 'sının, Kar ${ }^{+}$ örneklerinin 55 (\%91.6) ve 14 (\%23.3)'ünün ile Karº̈rneklerinin 36 (\%72) ve 4 (\%8)'inin sirasiyla Staphylococcus aureus (S. aureus) ve olası B. cereus'un yüksek düzeylerinden dolayı tüketime uygun olmadığını gösterdi. Aynı zamanda sonuçlar, toplam 270 örneğin 8 (\%2.96)'inin Listeria türleri ile; L. monocytogenes (\%0.37), Listeria ivanovii (\%1.85), Listeria grayi (\%0.37), Listeria seeligeri (\%0.37) ile kontamine olduğunu göstermiştir. E. coli kontaminasyonu, PS ve Kar gruplarında sırası ile \%7.5 ve \%4 oranında tespit edilmiştir. Salmonella spp. incelenen sandviç örneklerinin hiçbirinde tespit edilmemiştir. Bunun yanı sıra incelemelerden elde edilen koliformların ve AMC ( $\left.\geq 10^{6} \mathrm{kob} \mathrm{g}^{-1}\right)^{\prime}$ 'nın yüksek sayıları da işlenmiş sıcak sandviçlerin hijyenik durumlarının oldukça kötü olduğunu gösterdi. Sonuçlar, bu çalışmada incelenen sıcak sandviçlerin büyük halk sağlı̆̆ı endişesi yarattı̆̆ını göstermektedir.

Anahtar sözcükler: Halk sağlığ1, mikrobiyolojik kalite, sandviç, tüketime hazır gıda.

\section{Introduction}

The consumption of foods contaminated with foodborne pathogenic microorganisms and microbial toxins are responsible for deaths, illnesses, hospitalization, and economic losses (38). Due to their widespread nature, foodborne diseases (FBD), especially gastrointestinal infections, have negative effects on human health. However the symptoms are often mild and self-limiting, and therefore many patients do not consult a doctor, fecal samples are rarely examined, and most cases are sporadic rather than part of an outbreak (19). Eating out has increased in popularity over recent years, with two-thirds of the population rarely or routinely consuming takeaways in 2000 (3). Other than well-known restaurants and restaurants chains, consumers can find many alternatives, such as ready to eat (RTE) sandwiches and 
takeaways, in order to eat out. However, such prepared foods are considered to be susceptible to post-preparation contamination by pathogenic bacteria (37). The country's economic circumstances, social difficulties, life styles and presence of urban characteristics, among other factors, contribute to the growth of the informal sector of the economy, including street food vending. Street food is defined as "ready-to eat foods and beverages manufactured and/or sold by vendors and peddlers especially in street and other similar public places" by the Food and Agriculture Organization (2). The streetvended food industry provides employment and cheap RTE meals to a large proportion of the population in developing countries like Turkey, yet little is known about its role in the transmission of FBD. The immunocompromised people, undergoing steroid treatments and young children are more susceptible to FBD. Therefore, especially street-vended foods sold nearby hospitals and schools are of high health concern.

This study aimed to investigate the microbiological quality and the safety of RTE sandwiches available from street vendors located around hospitals and schools.

\section{Materials and Methods}

Sampling: The samples were collected in packages after preparation in the same manner as how a consumer would buy them. On reaching the laboratory, product type, purchase date and place of the samples were recorded and the samples kept in their original packages, not in a cooling box so as to replicate consumer behavior, until beginning of the analysis. The time elapsed between preparation of the sandwiches and analysis was $20 \mathrm{~min}$. CS ( $\mathrm{n}=80$ samples), SS ( $\mathrm{n}=80$ samples), $\mathrm{Mix}^{+}(\mathrm{n}=60$ samples) and $\mathrm{Mix}^{-}(\mathrm{n}=50$ samples) investigated in this study were periodically obtained from vendors between the period of July and September 2012.

Microbiological examinations: In order to provide a homogeneous mixture of bread and ingredients, twentyfive grams from each composite sample was weighed and homogenized with $225 \mathrm{ml}$ saline peptone solution $(8.5 \%$ saline $+1 \%$ peptone) in a Bag Mixer (Interscience, France) for two min. The homogenates were then submitted to serial 10-fold dilutions and the following procedures were performed. All media and chemicals used in this study were supplied from Oxoid, Hampshire, UK.

Aerobic mesophilic counts (AMC), yeast and moulds $(Y M)$ : The enumerations of AMC were determined from duplicate $0.1 \mathrm{ml}$ samples of appropriate dilutions $\left(10^{-3}\right.$ and $10^{-4}$ ) on Plate Count Agar (Oxoid CM325) at $30^{\circ} \mathrm{C}$ for 3 days (8). The levels of YM were determined in duplicate $0.1 \mathrm{ml}$ samples from appropriate dilutions $\left(10^{-1}\right.$ and $10^{-2}$ ) on Potato Dextrose Agar (Oxoid CM139, desirable acidified with $10 \%$ tartaric acid) at $21{ }^{\circ} \mathrm{C}$ for 5 days (26).
Coliform counts and E. coli: The numbers of coliforms were determined using The Most Probable Number (MPN) method with three series of dilutions $\left(10^{-1}\right.$ to $10^{-3}$ ). One $\mathrm{ml}$ of each dilution was transferred into tubes containing Lauryl Sulphate Tryptose broth (Oxoid CM451) and to Durham tubes by using a sterile pipette. The tubes were incubated at $37^{\circ} \mathrm{C}$ for $48 \mathrm{~h}$. All tubes became turbid; those that produced gas were selected and one loop full from each selected dilution was transferred into tubes containing EC Broth (Oxoid CM0853), then incubated at $45^{\circ} \mathrm{C}$ for $48 \mathrm{~h}$. In order to determine presumptive $E$. coli, one loop full from the samples that gave positive reactions in EC Broth was transferred into tubes containing tryptone water (Oxoid CM87) and incubated at $45^{\circ} \mathrm{C}$ for $48 \mathrm{~h}$. After the incubation period, the tubes were examined for indole production (6).

Staphylococcus aureus: In order to isolate $S$. aureus, $0.1 \mathrm{ml}$ homogenates from appropriate dilutions $\left(10^{-1}\right.$ to $\left.10^{-3}\right)$ were plated out in duplicate on Baird Parker Agar (Oxoid CM275) with egg yolk tellurite emulsion (Oxoid SR0054C, $50 \mathrm{ml} \mathrm{L}^{-1}$ ) by spreading with a Drigalsky handle and incubated at $37^{\circ} \mathrm{C}$ for $48 \mathrm{~h}$ (8). The diagnostic black colonies with halo were chosen and confirmed by a Staphaurex rapid test kit (20). S. aureus ATCC 33592 was used as positive control.

Bacillus cereus: Samples $(0.1 \mathrm{ml})$ from the $10^{-1}$ to $10^{-3}$ dilutions were taken and spread on duplicate Petri dishes containing Mannitol Egg Yolk Polymyxin Agar (Oxoid CM0929) supplemented with egg yolk emulsion (Oxoid SR0047, 10\% v/v) and polymyxin B (Oxoid SR00991, vial $/ 500 \mathrm{ml}$ ). The Petri dishes were then incubated at $30^{\circ} \mathrm{C}$ for $24 \mathrm{~h}$. After the incubation period, typical $B$. cereus colonies were selected, from which at least five were used in order to define presumptive $B$. cereus (5). The result was expressed in Colony Forming Units per gram of sandwich $\left(\mathrm{cfu} \mathrm{g}^{-1}\right)$, then indicated as $\log _{10} \mathrm{~g}^{-1}$ counts.

Salmonella spp.: Homogenization of the samples (25 g each) was carried out in a stomacher bag containing $225 \mathrm{ml}$ buffered peptone water (Oxoid CM509). The homogenized samples were incubated at $37^{\circ} \mathrm{C}$ for $24 \mathrm{~h}$. Then, $0.1 \mathrm{ml}$ from the dilutions for each sample were transferred into Rappaport Vassiliadis Enrichment Broth (Oxoid CM866) and Selenite Cystine broths (Oxoid CM0699) and incubated at $42^{\circ} \mathrm{C}$ and $37^{\circ} \mathrm{C}$ for $24 \mathrm{~h}$ respectively. One loopful from each enrichment broth was taken and spread on Brilliant Green Agar (Oxoid CM0263) and Xylose Lysine Desoxycholate Agar (Oxoid CM0469). The plates were then incubated at $37^{\circ} \mathrm{C}$ for $24 \mathrm{~h}$. Presumptive Salmonella colonies were identified by a salmonella latex test kit (Oxoid FT0203A) (4). Salmonella Enteritidis ATCC 13076 was used as positive control.

Listeria monocytogenes: In order to determine the presence of $L$. monocytogenes, examinations were 
performed using a two-step enrichment procedure (1); 25 g sample was diluted and homogenized in $225 \mathrm{ml}$ of Half Fraser broth (Oxoid CM0895) with Half Fraser supplement (Oxoid SR166) and incubated at $30^{\circ} \mathrm{C}$ for 48 h. A subset of $0.1 \mathrm{ml}$ was then inoculated in tubes containing $10 \mathrm{ml}$ Fraser broth (Oxoid CM0895) with Fraser supplement (Oxoid SR156) and incubated at $37^{\circ} \mathrm{C}$ for $24 \mathrm{~h}$. Subsequently, one loopful from each tube was streaked onto Oxford Agar (Oxoid CM856, added with oxford supplement, 1 vial $/ 500 \mathrm{ml}$, Oxoid SR140) and incubated at $37^{\circ} \mathrm{C}$ for $48 \mathrm{~h}$. Colonies showing Listeria spp. characteristic were taken and identified using the Microbact 12L (Listeria Identification System, Oxoid MB1128) system according to the manufacturer's instructions. L. monocytogenes ATCC 13932 (serotype 4b) and ATCC 19111 (serotype 1/2a) were used as positive controls.

\section{Results}

The incidence and levels of microorganisms isolated from the samples are shown in Table 1 and Table 2 . Overall, the data indicated that although no Salmonella spp. was found in any of the samples analyzed, the microbiological quality of the sandwiches investigated was very poor. Of particular concern was the isolation of L. monocytogenes in $0.37 \%$ ( 1 out of 270 ) of the sandwiches made with $\mathrm{Mix}^{+}$sample (Table 3). L. ivanovii was found in $1.85 \%$ of the samples (5 out of 270), in particular in CS and $\mathrm{Mix}^{+}$samples. In one Mix, L. ivanovii was the most common Listeria spp. For all samples, high AMC (100\%), total coliforms $(11.1 \%, 30$ out of 270$), E$. coli $(2.96 \%, 8$ out of 270$)$, presumptive $B$. cereus $(9.6 \%, 26$ out of 270$)$ and $S$. aureus $(70.7 \%, 191$ out of 270), were found (Tables 1 and 2). The results of this study showed that the numbers of E. coli, B. cereus

Table 1. Incidence (\%) and counts of bacteria found in sandwiches sold around hospitals and schools. Tablo 1. Hastane ve okullar çevresinde satılan sandviçlerde bulunan bakteri sayıları ve oranları (\%).

\begin{tabular}{|c|c|c|c|c|c|c|}
\hline $\begin{array}{c}\text { Type of } \\
\text { sandwich }\end{array}$ & $\begin{array}{l}\text { No. of } \\
\text { samples } \\
\text { tested }^{\mathrm{n}}\end{array}$ & $\begin{array}{c}\mathrm{AMC}^{\mathrm{a}} \\
\log _{10} \mathrm{cfu} / \mathrm{g}\end{array}$ & $\begin{array}{c}\text { Yeast }^{\mathrm{a}} \\
\log _{10} \mathrm{cfu} / \mathrm{g} \text { (no of } \\
\text { positive samples, \%) }\end{array}$ & $\begin{array}{c}\text { Mould }^{\mathrm{a}} \\
\log _{10} \mathrm{cfu} / \mathrm{g} \text { (no of } \\
\text { positive samples, \%) }\end{array}$ & $\begin{array}{c}\text { Coliforms }^{\mathrm{b}} \\
\text { MPN (no of positive } \\
\text { samples, \%) }\end{array}$ & $\begin{array}{c}\text { E. coli } \\
\text { MPN (no of positive } \\
\text { samples, \%) }\end{array}$ \\
\hline $\mathrm{CS}$ & 80 & $4.0-6.64$ & $\begin{array}{c}2.0-3.0 \\
27(33.75 \%)\end{array}$ & $\begin{array}{c}2.0-3.39 \\
30(37.5 \%)\end{array}$ & $\begin{array}{c}10-630 \\
10(12.5 \%)\end{array}$ & $\begin{array}{c}10-350 \\
6(7.5 \%)\end{array}$ \\
\hline $\mathrm{SS}$ & 80 & $3.0-5.90$ & $\begin{array}{c}2.0-3.32 \\
37(46.25 \%)\end{array}$ & $\begin{array}{c}2.0-3.65 \\
18(22.5 \%)\end{array}$ & $\begin{array}{c}100 \pm 0 \\
3(3.75 \%)\end{array}$ & ND \\
\hline $\operatorname{Mix}^{+}$ & 60 & $3.30-7.04$ & $\begin{array}{c}2.0-3.84 \\
28(35.0 \%)\end{array}$ & $\begin{array}{l}2.07-3.74 \\
39(65 \%)\end{array}$ & $\begin{array}{c}>1100 \\
13(21.6 \%)\end{array}$ & ND \\
\hline $\operatorname{Mix}^{-}$ & 50 & $3.0-6.69$ & $\begin{array}{c}2.0-3.60 \\
12(24.0 \%)\end{array}$ & $\begin{array}{c}2.0-3.49 \\
16(32 \%)\end{array}$ & $\begin{array}{l}>1100 \\
4(8.0 \%)\end{array}$ & $\begin{array}{l}>1100 \\
2(4.0 \%)\end{array}$ \\
\hline Totally & 270 & $3.0-7.04$ & $\begin{array}{c}2.0-3.84 \\
104(38.52 \%)\end{array}$ & $\begin{array}{c}2.0-3.74 \\
103(38.15 \%)\end{array}$ & $\begin{array}{c}10->1100 \\
30(11.11 \%)\end{array}$ & $\begin{array}{l}10->1100 \\
8(2.96 \%)\end{array}$ \\
\hline
\end{tabular}

${ }^{\mathrm{a}}: \log _{10} \mathrm{cfu} \mathrm{g}^{-1}$

b: Most Probable Number

${ }^{\mathrm{n}}$ : All samples were negative for Salmonella spp.

Table 2. The presence and incidence (\%) of some pathogenic bacteria in the tested sandwiches.

Tablo 2. Test edilen sandviçlerdeki bazı patojen bakteri varlığı ve oranları (\%).

\begin{tabular}{|c|c|c|c|c|}
\hline $\begin{array}{l}\text { Type of } \\
\text { sandwich }\end{array}$ & $\begin{array}{l}\text { No. of samples } \\
\text { tested }^{\mathrm{n}}\end{array}$ & $\begin{array}{c}\text { S. aureus }{ }^{\mathrm{a}} \\
\log _{10} \mathrm{cfu} / \mathrm{g} \text { (no of positive samples, \%) }\end{array}$ & $\begin{array}{c}\text { B. } \text { cereus }^{*} \\
\log _{10} \mathrm{cfu} / \mathrm{g} \text { (no of positive samples, } \% \text { ) }\end{array}$ & $\begin{array}{c}\text { Salmonella } \\
\operatorname{spp}^{\mathrm{n}}\end{array}$ \\
\hline $\mathrm{CS}$ & 80 & $\begin{array}{c}2.50-5.07 \\
55(68.75 \%)\end{array}$ & $\begin{array}{l}2.0-2.93 \\
6(7.5 \%)\end{array}$ & ND \\
\hline SS & 80 & $\begin{array}{c}2.0-4.63 \\
45(56.25 \%)\end{array}$ & $\begin{array}{l}2.0-2.32 \\
2(2.5 \%)\end{array}$ & ND \\
\hline $\mathrm{Mix}^{+}$ & 60 & $\begin{array}{c}2.0-4.90 \\
55(91.6 \%)\end{array}$ & $\begin{array}{c}2.0-3.20 \\
14(23.3 \%)\end{array}$ & ND \\
\hline $\mathrm{Mix}^{-}$ & 50 & $\begin{array}{c}2.07-5.74 \\
36(72.0 \%)\end{array}$ & $\begin{array}{l}2.0-2.35 \\
4(8.0 \%)\end{array}$ & ND \\
\hline Totally & 270 & $\begin{array}{c}2.0-5.74 \\
191(70.74 \%)\end{array}$ & $\begin{array}{c}2.0-3.20 \\
26(9.62 \%)\end{array}$ & \\
\hline
\end{tabular}

\footnotetext{
${ }^{\mathrm{a}}: \log _{10} \mathrm{cfu} \mathrm{g}^{-1}$

b: Most Probable Number

*: Presumptive $B$. cereus

n: All samples were negative for Salmonella spp.

ND: Not Detected
} 
Table 3. Types of Listeria spp. in sandwiches.

Tablo 3. Sandviçlerdeki Listeria spp. Tipleri.

\begin{tabular}{cccccc}
\hline $\begin{array}{c}\text { Type of } \\
\text { sandwich }\end{array}$ & $\begin{array}{c}\text { No. of samples } \\
\text { tested }^{c}\end{array}$ & $\begin{array}{c}\text { L. monocytogenes } \\
\text { No. and \% of } \\
\text { positive samples }\end{array}$ & $\begin{array}{c}\text { L. ivanovii } \\
\text { No. and \% of } \\
\text { positive samples }\end{array}$ & $\begin{array}{c}\text { L. grayi } \\
\text { positive samples }\end{array}$ & $\begin{array}{c}\text { No. and \% of } \\
\text { positive samples }\end{array}$ \\
\hline CS & 80 & ND & $2(2.5 \%)$ & $1(1.25 \%)$ & ND \\
SS & 80 & ND & ND & ND & ND \\
Mix $^{+}$ & 60 & $1(1.6 \%)$ & $2(3.3 \%)$ & ND & $1(1.6 \%)$ \\
Mix $^{-}$ & 50 & ND & $1(2 \%)$ & ND & ND \\
Totally & 270 & $1(0.37 \%)$ & $5(1.85 \%)$ & $1(0.37 \%)$ & $1(0.37 \%)$ \\
\hline
\end{tabular}

${ }^{\mathrm{c}}$ : For the presence/absence test

ND: Not Detected

and $S$. aureus exceeded the safety levels stated in the Turkish Food Codex (7).

\section{Discussion and Conclusion}

The high microbiological contamination could be due to post-contamination, between preparation and consumption. These findings suggest that some changes in production practices should be made to enhance the microbiological quality of these foods, in particular with regard to the AMC and $S$. aureus levels. Higher-thandesirable numbers of mould and yeast in tested samples may have arisen from nonfresh bread and/or ingredients with low microbiological quality. Coliforms and E. coli may contaminate sandwiches during processing through contamination and/or faecal material as a result of poor sanitary practices, improper handling and improper hygiene conditions. Bostan and et al. (13) and Fang et al. (21) detected E. coli in RTE foods at rates of $71.9 \%$ $(\mathrm{n}=96)$ and $88 \%(\mathrm{n}=50)$, respectively. In our study, we found the rate of $E$. coli to be relatively low, $2.96 \%$. The main reason for this difference might be the high temperature application used by the vendors in this study to make sandwiches just before collecting samples. Şireli and Gücükoğlu (36) identified Listeria spp. in 13\% of RTE foods ( $\mathrm{n}=100), 10 \%$ of which was L. monocytogenes. We detected 3\% $(\mathrm{n}=270)$ and $0.37 \%$ Listeria $\mathrm{spp}$. and $L$. monocytogenes, respectively with the same method. This result is also similar with Shen et al. (33), Little et al. (24), Christison et al. (16), and Bouayad and Hamdi (14), who isolated L. monocytogenes in $2.97 \%, 2.7 \%, 4 \%$ and $2.6 \%$ of RTE food samples respectively. However, Meloni et al. (28) found that $9.5 \%$ of RTE products were contaminated with L. monocytogenes. Mouspye and Von Holly (29), Cho et al. (17), Rodriguez et al (31), and Balzaretti and Marzano (10) found neither Listeria spp. nor Salmonella spp. in any RTE products. However, salmonellosis was associated with the consumption of sandwiches by Boxall et al. (15).

Similarly, L. monocytogenes was found in sandwiches that have been associated with outbreaks in the United Kingdom $(18,24,25,30,34)$ and in Switzerland (12). Of the RTE sandwiches collected and analyzed in this study, $1(0.37 \%)$ sample out of 270 was found to be contaminated with L. monocytogenes. This $L$. monocytogenes contamination likely resulted from (i) Insufficient heat treatment to kill the organism or (ii) Crosscontamination through air and equipment (14). Christison et al. (16) and Garcia et al. (22) determined Salmonella spp. in 11 out 70 and 5 out 103 samples tested, respectively. Aycicek et al. (9) detected of $S$. aureus in RTE meals from military cafeterias in 48 (9.4\%) samples. Bezerra et al. (11) pointed out that 33 $(31.4 \%)$ of hamburgers tested were unsuitable for human consumption, testing positive for coliforms and Staphylococcus at unacceptably high levels; high levels of microbiological contamination were also detected on the hands of the food handlers. According to Meldrum et al. (27) one of the food types with the poorest microbiological quality is egg mayonnaise sandwiches; when 475 were tested for $S$. aureus and $L$. monocytogenes, $4(0.8 \%)$ and $2(0.4 \%)$ respectively were found to be contaminated. While Hanashiro et al. (23) did not detect any $S$. aureus strains, they found B. cereus in 5 of 33 RTE sandwiches.

In a questionnaire conducted by Sert and Kapusuz (32), it was reported that although the overall opinions of students regarding foods sold by street vendors were generally negative, they preferred these foods because of the low cost and fast service. Government and the food industry each has an important role to play in identifying, assessing and managing risks associated with the consumption of foods (35). The large number of contamination index microorganisms (E. coli and coliforms) and pathogens (S. aureus, L. monocytogenes and $B$. cereus) found in the sandwich samples tested in this research suggests that these RTE foods pose a potential health hazard to consumers, especially considering that they were being sold near schools and hospitals. The results show that these sandwiches were produced under low hygienic conditions and with poor ingredient storage conditions. Improper handling and improper hygiene might lead to the contamination of 
food. Training in personal hygiene, good manufacturing practices (GMPs), cleaning and sanitation procedures could improve the microbial quality of the sandwiches served. It has been clearly understood from the abovementioned studies that almost all street-vended food is of poor microbiological quality. With the development of modern transportation techniques and vehicles, foodborne infection/intoxication agents may meet with humans who have not encountered these agents before and are consequently vulnerable to infection. This might be in two ways; first for touristic reasons and second due to imported food and food ingredients. Therefore consumption of uncontrolled street-vended foods could have serious implications on public health.

\section{References}

1. Anonymous (1996): ISO 11290-1, Microbiology of food and animal feeding stuffs. Horizontal method for the detection and enumeration of Listeria monocytogenes. Part 1: Detection method.

2. Anonymous (1997): Food Agriculture Organization FAO. Street foods. Report of an FAO technical meeting on street foods Calcutta, India, 6-9 November 1995. FAO Food Nutrit paper no:63, Rome.

3. Anonymous (2001): COI Communications and Food Standards Agency. Consumer Attitudes to Food Standards. COI Ref: 4695. Taylor Nelson Sofres plc.

4. Anonymous (2002): ISO 6579, Microbiology of food and animal feeding stuffs. Horizontal method for the detection of Salmonella spp.

5. Anonymous (2004): ISO 7932, Microbiology of food and animal feeding stuffs. Horizontal method for the enumeration of presumptive Bacillus cereus. Colony-count technique at 30 degrees $C$.

6. Anonymous (2005): ISO 7251, Microbiology of food and animal feeding stuffs. Horizontal method for the detection and enumeration of presumptive Escherichia coli. Most probable technique.

7. Anonymous (2011): Turkish Food Codex Regulation, Notification of Microbiological Criteria.

8. Aycicek H, Sarimehmetoglu B, Cakiroglu S (2004): Assessment of the microbiological quality of meals sampled at the meal serving units of a military hospital in Ankara, Turkey. Food Cont, 15, 379-384.

9. Aycicek H, Cakiroglu S, Stevenson TH (2005): Incidence of Staphylococcus aureus in ready-to-eat meals from military cafeterias in Ankara, Turkey. Food Cont, 16, 531-534.

10. Balzaretti CM, Marzano MA (2013): Prevention of travel-related foodborne diseases: Microbiological risk assessment of food handlers and ready-to-eat foods in northern Italy airport restaurants. Food Cont, 29, 202207.

11. Bezerra ACD, Dos Reis RB, Bastos DHM (2010): Microbiological Quality of Hamburgers Sold in The Streets of Cuiabá - MT, Brazil and Vendor HygieneAwareness. Cienc Tecnol Aliment, 30, 520-524.

12. Blatter S, Giezendanner N, Stephan R, Zweifel C (2010): Phenotypic and molecular typing of Listeria monocytogenes isolated from the processing environment and products of a sandwich-producing plant. Food Cont, 21, 1519-1523.

13. Bostan K, Cetin O, Ergun O (2005): The Presence Of Verotoxinogenic E. coli in Some Foods. Vet Glasnik, 59, 427-436.

14. Bouayad L, Hamdi TM (2012): Prevalence of Listeria spp. in ready to eat foods (RTE) from Algiers (Algeria). Food Cont, 23, 397-399.

15. Boxall NS, Adak GK, De Pinna E, Gillespie IA (2011): A Salmonella Typhimurium phage type (PT) U320 outbreak in England, 2008: continuation of a trend involving ready-to-eat products. Epidemiol Infect, 139, 1936-1944.

16. Christison CA, Lindsay D, von Holy A (2008): Microbiological survey of ready-to-eat foods and associated preparation surfaces in retail delicatessens, Johannesburg, South Africa. Food Cont, 19, 727-733.

17. Cho JI, Cheung CY, Lee SM, Ko SI, Kim KH, Hwang IS, Kim SH, Cho SY, Lim CJ, Lee KH, Kim KS, Ha SD (2011): Assessment of Microbial Contamination Levels of Street-Vended Foods in Korea. J Food Safety 31, 41-47.

18. Dawson SJ, Evans MR, Willby D, Bardwell J, Chamberlain N, Lewis DA (2006): Listeria outbreak associated with sandwich consumption from a hospital retail shop, United Kingdom. Euro Surveillance, 11, 89-91.

19. Evans MR, Sarvotham T, Thomas DR, Howard AJ (2006): Domestic and travel-related foodborne gastrointestinal illness in a population health survey. Epidemiol Infect, 134, 686-693.

20. Fang TJ, Chen CY, Kuo WY (1999): Microbiological quality and incidence of Staphylococcus aureus and Bacillus cereus in vegetarian food products. Food Microbiol, 16, 385-391.

21. Fang TJ, Wei QK, Liao CW, Hung MJ, Wang, TH (2003): Microbiological quality of $18^{\circ} \mathrm{C}$ ready-to-eat food products sold in Taiwan. Int J Food Microbiol, 80, 241250.

22. Garcia TE, Saucedo CL, Ayala BZ, Thompson MR, Cogco LG, Martinez AM, Gutierrez AE (2004): Prevalence of Escherichia coli and Salmonella spp. in Street-Vended Food of Open Markets (Tianguis) and General Hygienic and Trading Practices in Mexico City. Epidemiol Infect, 132, 1181-1184.

23. Hanashiro A, Morita M, Matt GR, Matt MH, Torres EAFS (2005): Microbiological quality of selected street foods from a restricted area of Sao Paulo city, Brazil. Food Cont, 16, 439-444.

24. Little CL, Barrett NJ, Grant K, McLauchlin J (2008): Microbiological Safety of Sandwiches from Hospitals and Other Health Care Establishments in the United Kingdom with a Focus on Listeria monocytogenes and Other Listeria Species. J Food Protect, 71, 309-318.

25. Little CL, Sagoo SK, Gillespie IA, Grant K, McLauchlin J (2009): Prevalence and level of Listeria monocytogenes and other Listeria species in selected retail ready-to-eat foods in the United Kingdom. J Food Protect, 72, 1869-1877.

26. Lues JFR, Rasephei MR, Venter P, Theron MM (2006):Assessing food safety and associated food handling practices in street food vending. Int J Environ Health Res, 16, 319 - 328 . 
27. Meldrum RJ, Smith RMM, Ellis P, Garside J (2006): Microbiological quality of randomly selected ready-to-eat foods sampled between 2003 and 2005 in Wales, UK. on behalf of the Welsh Food Microbiological Forum. Int J Food Microbiol, 108, 397-400.

28. Meloni D, Galluzzo P, Mureddu A, Piras F, Griffiths M, Mazzette R (2009): Listeria monocytogenes in RTE foods marketed in Italy: prevalence and automated EcoRI ribotyping of the isolates.Int J Food Microbiol, 129, 166-173.

29. Mosupye FM, von Holy A (1999): Microbiological quality and safety of ready-to-eat street-vended foods in Johannesburg, South Africa. J Food Protect, 62, 1278-1284.

30. Pesavento G, Ducci B, Nieri D, Comodo N, Lo Nostro A (2010): Prevalence and antibiotic susceptibility of Listeria spp. isolated from raw meat and retail foods. Food Cont, 21, 708-713.

31. Rodriguez M, Valero A, Carrasco E, Pérez-Rodríguez F, Posada GD, Zurera G (2011): Hygienic conditions and microbiological status of chilled Ready-to-Eat products served in Southern Spanish hospitals. Food Cont, 22, 874882.

32. Sert S, Kapusuz F (2010): Street Foods: Research on Students' Opinions and Reasons for Preferring. Electron J Food Technol, 5, 25-35.

33. Shen Y, Liu Y, Zhang Y, Cripe J, Conway W, Meng J, Hall G, Bhagwat AA (2006): Isolation and Characterization of Listeria monocytogenes Isolates From Ready-To-Eat Foods in Florida. Appl Environ Microbiol, 72, 5073-5076.
34. Shetty A, McLauchlin J, Grant K, O'Brien D, Howard T, Davies EM (2009): Outbreak of Listeria monocytogenes in an oncology unit associated with sandwiches consumed in hospital. J Hosp Infect, 72, 332-336.

35. Stringer M (2005): Summary report, Food safety objectives-role in microbiological food safety management. Food Cont, 16, 775-794.

36. Şireli UT, Gücükoğlu A (2008): Prevalence and Antibiotic Resistance of Listeria spp. Isolated from Ready-to-Eat Foods in Ankara. Turk J Vet Anim Sci, 32, 131-135.

37. Wilson IG (1996): Occurrence of Listeria monocytogenes in pre-packed retail sandwiches. Epidemiol Infect, 117, 89-93.

38. Yoon Y, Kim SR, Kang DH, Shim WB, Seo E, Chung DH (2008): Microbial assessment in the school foodservices and recommendations for food safety improvement. J Food Sci, 73, 304-313.

Geliş tarihi: 15.05.2013 / Kabul tarihi: 07.03.2014
Address for correspondence:
Assist. Prof. Sadik Buyukyoruk, PhD, DVM
Adnan Menderes University,
Faculty of Veterinary Medicine,
Department of Food Hygiene and Technology, 09016, Işıkl, Aydın,TURKEY.
e-mail:sbuyukyoruk@adu.edu.tr 